\title{
Introduction. Imaginations and Constructions of South Asia: An Enchanting Abstraction?
}

\section{Aminah Mohammad-Arif}

\section{(2) OpenEdition}

1 Journals

Electronic version

URL: https://journals.openedition.org/samaj/3800

DOI: 10.4000/samaj.3800

ISSN: 1960-6060

Publisher

Association pour la recherche sur l'Asie du Sud (ARAS)

\section{Electronic reference}

Aminah Mohammad-Arif, "Introduction. Imaginations and Constructions of South Asia: An Enchanting Abstraction?", South Asia Multidisciplinary Academic Journal [Online], 10 | 2014, Online since 25

December 2014, connection on 21 September 2021. URL: http://journals.openedition.org/samaj/3800 ; DOI: https://doi.org/10.4000/samaj.3800

This text was automatically generated on 21 September 2021.

\section{$(1) \Theta \Theta$}

This work is licensed under a Creative Commons Attribution-NonCommercial-NoDerivatives 4.0 International License. 


\title{
Introduction. Imaginations and Constructions of South Asia: An Enchanting Abstraction?
}

\author{
Aminah Mohammad-Arif
}

\section{Introduction 1}

1 The idea for this special issue of SAMAJ ${ }^{2}$ came up in 2010 when the Directorial Committee in charge of France's largest research centre on South Asian studies tried to change its name from Centre d'Études de l'Inde et de l'Asie du Sud (Centre for Indian and South Asian Studies) to Centre d'Études Sud-Asiatiques (Centre for South Asian Studies). Our institutions, the EHESS and the CNRS, as well as a number of colleagues, objected to the change of the name, arguing that 'Asie du Sud' was too unfamiliar a term in France. The proposal was dropped but the objections triggered a curiosity to know more about the history of the name, its multiple meanings and uses, and the notion(s) behind it. ${ }^{4}$

The term 'South Asia' is indeed interesting for several reasons. First, it refers to a region ${ }^{5}$ where several religions, that may be identified with different 'civilizations', have been interacting, potentially challenging the idea that a region forms a cultural realm. Second is the ambivalent role of British colonization, which on the one hand laid the foundations (partly started by the Mughals) for a mental representation of the region, through its unification policies, and on the other contributed to create divisions between distinct states and across common cultures at the time of Independence. Third, the Indian Subcontinent, a more familiar term for 'South Asia', has been characterized by a tragic history that witnessed several partitions rendering notions of 'region' and 'regionalism' particularly sensitive. Fourth is the peculiar dominating position of a single country, India, and the specific nature of another one, Pakistan, which is the only country, along with Israel, established in the name of a religion (see Devji 2013). This gives both region 
and regionalism a unique flavour as compared to regional constructions in other parts of the world.

3 In this introduction, I will focus on the polysemy of the term 'South Asia', and the notions behind it. To highlight some of the underlying debates behind the politics of naming and the formation of a region(alism), I will take as entry points the multi-layered processes of construction, and deconstruction (through contestations), by various actors. I will thus try to answer the following questions: what does the expression 'South Asia' convey that 'Indian Subcontinent' does not? In other words, as a term, is 'South Asia' systematically interchangeable with 'Indian Subcontinent'? The name 'South Asia' is only a few decades old, but how new is the process of imagining and constructing the region as a common cultural space? What are the underlying stakes and ideologies behind such constructions? In the process, different meanings of regionalism will be examined: first is the top-down construction of a series of economic and political institutions, whose aim is to foster collaboration between the different states of the Subcontinent; second is a bottom-up construction nurtured by a sentiment of belonging, which is expressed at the level of both emotions and practices.

Given the multiplicity of constructions, this special issue has been entitled 'Ideas of South Asia' but I will sometimes use the singular ('idea') whenever I mean South Asia as a civilizational entity. It should be noted that I am borrowing the phrase 'idea(s) of South Asia from Sunil Khilnani's The Idea of India (1997) not only because of its conceptual relevance but also because, as we shall see below, there may be some significant similitudes between both 'ideas'. Since the use of the term 'South Asia' is at the core of the discussion here, I will use 'Subcontinent' to refer to the region in descriptive terms without endorsing it with any particular meaning (however the use of the word 'Subcontinent' will also be discussed in the conclusion).

The number of publications dealing with the notion of South Asia is fairly limited. This lack of reflective research work on South Asia as a category could be interlinked to the fact that most scholars work on a single country of the region. However, a few projects have emerged, almost simultaneously, in the past few years, as if time had come to reflect upon South Asia in its multiple dimensions, the name itself, the notions behind it, the issue of regionalism and so on. Among these projects is a book entitled South Asia 2060 (2013), in which the authors (academics, journalists, policy-makers, etc.) mostly express their views about the chances of success of 'South Asia' as an expression of regional construction. The journal Seminar (2012) has also published a special issue entitled A country of our own: A Symposium on Re-imagining South Asia which includes essays reflecting on the notion as a civilizational entity defined by historical and cultural continuities. But as interesting as these essays are, they do not fully address the category 'South Asia' as such (see infra). A book published by David Gellner (2013) does deal with South Asia as an analytical category but limits itself to the (admittedly stimulating) notion of 'northern South Asia', and focuses on 'borderland lives'. Last but not least, the non-academic magazine Himal Southasian is devoted to publishing articles related to South Asia (see infra), including some that tackle the notion directly. The August 2008 special issue, entitled Southasian Exists, is a case in point, as several authors (including scholars, writers, journalists, human rights activists) comment on the notion of South Asia in short essays. Some of Himal Southasian's most significant articles have been assembled in a book edited by Kanak Mani Dixit, The Southasian Sensibility. But although Himal Southasian's articles are 
usually very articulate, they are not academic sources as such. This special issue will therefore attempt to partly fill the gap, although doing it is no easy chore.

Writing this introduction indeed turned out to be a difficult task for at least four reasons. First, the subject requires a constant shift from etymology to social sciences (see Emerson 1984: 14), i.e. from the name 'South Asia' to the multiple notion(s) behind it (region, regionalism, civilizational entity and so on), necessitating a constant vigilance so as not to confuse both. Second, it demands a multidisciplinary approach, including disciplines other than mine (anthropology), such as history and political science. Third, the magnitude of the task is such that some angles have been privileged (constructions from below, brief comparisons with Europe), while other aspects, which would have been interesting, have been left aside (such as the comparison with South America ${ }^{6}$ ) or only alluded to (like the geopolitical dimension). Fourth, the subject would necessitate thorough knowledge of several countries and parts of the Subcontinent whereas most of the empirical examples I have taken are only about India and Pakistan. The co-editor of this special issue, Blandine Ripert, and I have however solicited authors capable of covering other countries of the region (although unfortunately not all).

In this introduction, I will first examine the emergence of the category 'South Asia' by tracing the history of the term. In the process, without neglecting top-down constructions (as embodied by SAARC), I will pinpoint some of the contestations around the expression and the notions behind it, in order to highlight the limitations of the category, externally as well as internally. I will then show that, despite these caveats, 'South Asia' may not be a mere abstraction, by examining how the notion is constructed from below. In order to give anthropological substance to the argument, I will first study the everyday constructions of the notion and then focus on 'conscious' and more politicized constructions.

\section{Tracing the genealogy of the name}

8 It is not easy to determine who first coined the word 'South(ern) Asia'. The earliest occurrence I could find ${ }^{7}$ is mentioned in the title of a book by Horace Bleackley about a region that would correspond today to... Southeast Asia (except Ceylon): A Tour in Southern Asia: Indo-China, Malaya, Sumatra and Ceylon, 1925-1926, published in London in 1928.

9 There is however consensus that the word 'South Asia' officially emerged as a category to divide the Asian continent, in the wake of the establishment of area studies in the United States. ${ }^{8}$ This emergence was the outcome of two interlinked concerns: one was the development of scholarship on the ancient Indic civilization; the second was a strategic interest in the study of contemporary Asia as the Second World War had highlighted the shortage of specialists capable of dealing with economic, social and political issues in the region. As Nicholas Dirks (2003) explains, Norman Brown, a professor of Sanskrit at the University of Pennsylvania, was particularly instrumental in establishing this conjuncture and in subsequently shaping South Asian area studies between 1926 and 1966. Drawing from a book published by Brown in 1953, entitled The United States and India and Pakistan, Dirks points out that although Brown's endeavour to establish departments of South Asian studies in the United States was rooted in the aspiration to promote understanding and exchange between India, Pakistan and the United States, ${ }^{9}$ his own sense of Indian history was shaped by a vision whereby Hinduism and the Sanskrit 
language represented exclusively the cementing forces of Indian civilization, while Muslims were considered as the disruptors of India's cultural unity (2003: 7-10). As a result, Brown analyzed the partition of India in essentialist terms, as the following excerpts from his book show: 'the basis of Hindu-Muslim communalism lies in cultural differences', (Dirks 2003: 9). While this vision of Indian civilization was to have significant repercussions on the development of South Asian studies in American universities (Dirks 2003:9), it also implied that the use of the word 'South Asia' was not necessarily associated with a conceptualization of the region as a civilizational entity. Yet, the very fact of establishing interdisciplinary research centres on the Subcontinent, named after the term 'South Asia', has endorsed the region with some unity in academic circles and beyond. Similarly, the creation of journals, entitled South Asia(n)..., such as SAMAJ, contributes to construct the region as a cultural entity. That, in reality, India occupies centre stage in most area studies departments and publications is symptomatic of a peculiar feature characterizing the Subcontinent, mentioned above, i.e. the 'asymmetrical' presence of India in the region, an issue to which we will return later.

To come back to the history of the name 'South Asia' as such, the word was also used from the 1940 s to the 1970 s by policy-making institutions such as the American State Department, which published in 1959 a briefing document entitled The Subcontinent of South Asia, ${ }^{10}$ and international organizations like the United Nations and the World Bank.

11 The genealogy of the word thus shows that it was officially conceived and used outside the Subcontinent testifying to its exogeneity. Although this fact can hardly be disputed, it is however worth mentioning that there was an earlier occurrence of a close word to name the region and which was used by a person from the Subcontinent, Aga Khan III, the spiritual leader of the Khoja Ismailis. Thus, according to Ayesha Jalal and Anil Seal (1981), Aga Khan III, used 'Southern Asia' in a letter in English that he wrote in 1935 from London to Fazl-i Husain (1877-1936), the leader of the Punjab Unionist Party, before the emergence of the idea of separate sovereign-states. Concerned about the unity of Muslims which was hindered by the provincialism of the regions where they were in a majority, Aga Khan wrote:

[...] to 'make India what she is, i.e. a United States of Southern Asia', where the Muslims would work for all they were worth the majority provinces against the new federal centre. But 'our Indian patriotism, of course, should never leave any doubt and our Hindu countrymen must realise that the welfare of India as a whole... is as dear to us as it is to them... (Jalal \& Seal 1981: 449)

In the 1980s, the word 'South Asia' was given a new impetus with the creation of the South Asian Association for Regional Cooperation (SAARC). The idea of regional cooperation, stemming from the conception of the region as an entity, had been discussed in various conferences, before and just after Partition. ${ }^{11}$ It was not however until the 1980s that the first concrete proposal came up, leading to the creation of SAARC in 1985. With the formation of SAARC various agreements were established, such as the South Asia Free Trade Area, and events, such as the South Asia Youth Award or a South Asian Car Rally in 2007, starting from Bangladesh and ending in Maldives, that were meant to convert the idea of South Asia into 'living practices'. Another major symbolic step was the creation in 2007 of the South Asian University, a non-state, non-profit, self-governing international educational institution, based in Delhi. ${ }^{12}$ As per the agreement signed by all the member states, the objectives stated in article 2 include not only the bringing together of students and faculty from all the countries of SAARC (and beyond) but also the creation of 'a South Asian community by strengthening regional consciousness' ${ }^{13}$ The 
creation of SAARC and of its affiliate institutions thus endowed the term 'South Asia' with an official public meaning embedded in the local context while pressing forward the regional idea. In the process, the notion that South Asia refers to a region bound by history and culture was given an official and endogenous impulsion, as attested by point 2 of SAARC's charter. ${ }^{14}$

\section{The Aporias of 'South Asia'}

Several decades after its appearance and increasing use in regional and international institutional circles, the term 'South Asia' remains however largely debated and often contested as an artificial and exogenous category. It does not have a mythical tale, such as the story of Europa who gave her name to Europe..$^{15}$ Nor does the name have a 'sentimental force on its own' the way 'Hindustan' (in its broader meaning ${ }^{16}$ ) used to have from the $18^{\text {th }}$ century onwards (Bayly 1998: 39-44). The word exists in vernacular languages but only as a direct translation of the English term (Dakshin Asia in Hindi, Janubi Asia in Urdu, Dokkhin Ashia in Bengali, Dakunu Asiyawa in Sinhala, etc.). It is so rarely used in vernacular daily conversations that the mention of the word Dakshin Asia in a Hindi movie, Dhobi Ghat (Kiran Rao 2011), was highlighted for its unusualness in an article published in Himal Southasian (Dixit 2011a). Some even see 'South Asia' as an empty category, whose sole heuristic value might be that the word is politically neutral (Bose \& Jalal 1999: 3), as opposed to the 'Indian Subcontinent' which includes the name of one of the countries of the region. In this special issue, Sudipta Kaviraj questions the relevance of the notion of 'South Asia' when confronted with the challenges posed by the two political processes of modernity, nationalism and state-formation: the state formations of India, Pakistan and Bangladesh thus make it difficult 'to think of South Asia as a space of emotional inhabitance'.

In any case, the use of terms for the sake of political neutrality is not new in the history of the Subcontinent: Barrow notes for instance that while the British cartographers, initially associating the Subcontinent with the Mughal Empire, used the term 'Hindustan', to designate the region, the word 'India' imposed itself from the late $19^{\text {th }}$ century onwards, not only because 'Hindustan' had several meanings, either covering entire India or referring only to northern India, but also because the word had a Muslim connotation (and Bharatvarsha and Jambudvipa had a Hindu one) whereas 'India' was a more 'neutral' category that would better convey a meaning of the Subcontinent as a 'single, bounded and British political territory' (Barrow 2010: 40). The use of words, such as India or South Asia, mainly for the sake of neutrality has thus been a recurrence, which has continued after independence and has been used by individuals and groups well beyond official political and academic circles: in an article published in The Hindu, Bernard Haykel, commenting on the new branch created by Al-Qaida in South Asia (AQSA), whose Arabic name literally translates as 'The Base for Armed Struggle in the South Asian Subcontinent', writes for instance:

The Base for Armed Struggle in the South Asian Subcontinent is an odd name because the purist jihadis prefer traditional geographical labels, such as al-Sham for Syria, Khorasan for Iran and Central Asia, Bilad al-Haramayn for Arabia, al-Hind or Hindustan for India, and not those of British vintage such as the South Asian Subcontinent.' One suspects the choice has to do with the jihadis not wanting to use anything that approximates the word Hindu, or a name that would offend radical 
Pakistani sensibilities, and thus opted for the British designation instead (The Hindu, 11 Sept. 2014). and a notion raises a number of problems externally as well as internally. I will address here only those at the core of the original project of naming and constructing the region, leaving aside for instance academia's critique of 'area studies', as these debates have been well covered by scientific works (see in particular Sanjay Subrahmanyam's notion of 'connected histories', Subrahmanyam 1997). ${ }^{17}$ In this special issue, Jonathan Spencer, taking the example of Sri Lanka, interrogates the very notion of place as it does not reflect the movement and connection characterizing the island for centuries.

\section{A persistent invisibility}

Among the limitations of South Asia as a category is first the low intelligibility of the word. While the term 'South Asia' is gaining visibility in Anglo-Saxon countries, its use remains limited to academic and political circles: in the UK, for instance, which among Western countries has the greatest familiarity with India because of the colonial past, the word is largely accepted to name research centres, but 'Asian' rather than 'South Asian' is used to label the people of the Subcontinent. In France, the word is virtually inexistent ('Asie du Sud' made its official entry in the most consulted online dictionary, Wikipedia, only about a year ago) and is often confused with 'Southeast Asia'. This widespread confusion, much beyond France, between 'South Asia' and 'Southeast Asia' may take its roots in the fact that the first occurrence of 'Southeast Asia' ${ }^{18}$ appeared a century before 'South Asia' and included then, according to several authors, all or much of India. ${ }^{19}$ This low level of awareness about the very existence of the word and its meaning seems to be equally widespread among the populations of the region it designates. Admittedly, attempting to determine empirically the level of basic awareness, not to mention any sort of attachment or identification, about the notion of South Asia, at the level of both individual and collective representations, raises serious methodological and epistemological questions. Yet a field survey conducted in Bangalore in August 2012, among a small sample of middle-class and educated people, to gage their awareness of the category, their identification with the region and so on, did yield some interesting clues. It hinted at a fairly fuzzy knowledge of the word itself, the region it encompasses, etc.; like elsewhere in the world, the term 'South Asia' was often confused with 'Southeast Asia', some included China in the region, others Saudi Arabia and so on...

\section{Fluctuating boundaries}

17 A second limitation is the highly fluctuating definition of the geographical extent of 'South Asia'. Admittedly, this trait is not specific to the region as in other parts of the world debates and contestations also run high on geographical delimitations. Europe is a case in point: 'Europe was, and always had been, a highly unstable term. No one has ever been certain quite where its frontiers lie', thus notes Pagden (2002: 45). However, in comparison to the continents of Africa or South America, South Asia, as a Subcontinent, only has a partially immediate identifiable shape. Besides, even after the word got increasing international legitimation, its range was not fixed so much so that a general consensus over which countries ought to be encompassed in the definition of South Asia applies probably to only one country of the region... India! Even in that case, if South Asia

South Asia Multidisciplinary Academic Journal, 10 | 2014 
is defined as a historical and cultural entity, the inclusion of some regions located in India's margins, like the Northeast, raises questions among scholars, some suggesting that the Northeast should be classified in alternative entities like Zomia. ${ }^{20}$ This questioning, when coming from laypeople, can take on racial overtones as suggests the use by so-called 'mainland' Indians of derogatory terms against northeast people, such as 'Chinkis', suggesting an association with Chinese rather than Indians/South Asians. ${ }^{21}$ It is however with Southeast Asia that Indian northeast people have mainly been associated (Emmerson 1984).

18 In any case, whether in South Asia itself or in international institutions or research centres outside the region, there is no general consensus over which countries the notion encompasses: SAARC has included Afghanistan among its members while the World Bank has left it out. Some research centres have included Burma, as it was a province of British India till 1937 (testifying to the role of colonization in shaping the region much before the establishment of area studies in the United States), and Tibet, but leave Afghanistan and the Maldives out. The politics of naming can also be prone to a form of competition, including in research centres and universities, between the terms 'India' and 'South Asia', the latter term progressively taking precedence over the former term or coexisting with it: the French Centre d'Études de l'Inde added to its name 'Asie du Sud' (South Asia) in 1970 but chose not to remove 'Inde' (India), and thus became the Centre d'Études de l'Inde et de l'Asie du Sud. Conversely, the countries included in South Asia as per the SAARC definition may be listed elsewhere as per other classifications: hence Ceylon/Sri Lanka used to be frequently considered as part of Southeast Asia by scholars of the region (Emmerson 1984), probably as a result of colonization (the island was controlled in the 19 th century by the British who ruled Fiji and New Zealand, but not by those who governed Madras and Bombay, see Spencer in this special issue and Sivasundaram (2013); it is also worth consideration that Sri Lanka has a university called Southeastern created in the mid-1990s, see Spencer in this special issue). As for Pakistan, the Washington-based Middle-East Institute for instance includes a Center for Pakistan Studies, suggesting that it sees it as part of the Middle East. In both cases, religions, Theravada Buddhism (Emmerson 1984: 11) and Islam (Laurens 201322) have respectively been/were the uniting principle in the search for appropriate boundaries. However the perception of religious or cultural continuities has not always been the guiding principle as testifies the choice of the Pakistani State (including East Pakistan, later on Bangladesh) to be part of the now defunct South East Asia Treaty Organization (1954-1977), an organization born out of an Anglo-American initiative to counter communism: the conflicting relations with India had indeed contributed to Pakistan's decision to join SEATO. ${ }^{23}$

The fluctuation of boundaries when delineating a region is of course not new in the history of the Subcontinent, as Catherine Clémentin-Ojha's paper shows in this special issue, in which she discusses the words historically used in different languages to designate the region or parts of the region. Worth mentioning are also the discussions about the delineating and naming of regions that were under way during the movement for the creation of Pakistan. Admittedly, this comparison has its limitations since on the one hand the discussions encompassed the regions at a much smaller scale, while on the other hand they were to have much more dramatic political repercussions on the region. Yet, the idea of lumping together some areas, on the basis of religion or culture, or on the basis of some other considerations is entrenched in historical continuity. According to Ayesha Jalal, Choudhary Rahmat Ali (1897-1951), who famously coined the name 
'Pakistan', had also proposed the creation of a 'Bangistan' or a 'Bang-i Islamistan' by grouping Bengal and Assam, and an 'Osmanistan' for a would-be sovereign state of Hyderabad; he had also invented colourful names like 'Faruqistan, Mappalistan, Nasiristan' to cover several parts of British and princely India as well as present-day Sri Lanka (this meaning that, interestingly, Sri Lanka was also included in the imaginary Pakistan, see Jalal 2001: 392-393).

\section{The asymmetrical presence of India}

20 A third limitation is the perception that the term 'South Asia' is actually another name for India, leading thereby to political contestations at the scale of the region. The central and asymmetrical presence of India in various domains, including geography (except for Afghanistan, ${ }^{24}$ none of the SAARC countries can interact with another without crossing Indian territory) is such that India's neighbouring countries tend to perceive the category 'South Asia' as Delhi-centric. The issue is probably the most sensitive in Pakistan as behind the name lies the notion that the region forms a historical and cultural entity. In a way, to consider the region as an 'entity' calls into question the very foundation of the country which was born as an outcome of the idea that Hinduism and Islam formed two separate civilizations, a belief also shared by Hindu nationalists in India. In this special issue, Faisal Devji discusses the notion of 'Muslim community', as conceptualized by the intellectuals gathered in the Aligarh movement, who were struggling to find their place in the upcoming new political space. The use of the word 'South Asia' was thus banned in the department of international relations of Karachi University until 1989 as it was 'thought to be part of an India-centric thinking' (Zaidi 2009: 61). The contestation of the notion should also be seen in the light of the Pakistani State's own quandaries about the definition of its identity, at the crossroads of South Asia and the Middle East. The shift from South Asia to the Middle East started particularly after the breakaway of Bangladesh. Thus, one of the constant themes' of Zulfikar Ali Bhutto's regime was 'the need for Pakistan to develop closer links with the Islamic world and to look towards the Middle East rather than elsewhere in Asia' (Talbot 1998: 235). That said, the visibility in Pakistan of the term 'South Asia' is not necessarily insignificant as suggests for instance the name of a university specialized in computer science in Lahore: the University of South Asia (which uses USA as an acronym!). In any case, the perception that 'South Asia' is synonymous with India is, of course, not confined to Pakistan and can be encountered in other South Asian countries as well, testifying to a fear, largely shared in the Subcontinent, of the domination of India over its neighbouring countries. It should be however noted that the opposite argument is sometimes put forward, i.e. India might neglect the regional construct because it does not feel the need for it. According to Dixit, some claim that India 'does not need Subcontinental regionalism because by itself it incorporates much of South Asia by economic strength, geopolitical prowess and miscellany' (Dixit 2013: 32), while other countries will take greater economic and political advantages of regionalism. Whatever be the case, two countries neighbouring India have been particularly instrumental in promoting endogenous ideas of South Asia: Bangladesh, whose President, Ziaur Rahman, is believed to have initiated the proposal for the creation of SAARC; and Nepal where SAARC's headquarters are located. 


\section{The limited success of top-down political constructions}

21 A fourth limitation is that the abstract nature of the notion of 'South Asia' is reinforced by the ambiguous place of political cooperation in the institution, namely SAARC, that is supposed to embody the endogenous political project of South Asia. The organization, created mainly to ensure peace in the region that had been prey to several internal conflicts, enounces among its objectives the acceleration of 'economic growth, social progress and cultural development in the region' along with the promotion of 'an active collaboration and mutual assistance in the economic, social, cultural, technical and scientific fields'. ${ }^{25}$ In that, the major objectives of SAARC are not specific to the Subcontinent as for instance they bear a resemblance with the original aim of the European Economic Community when it was created in 1957 by the Treaty of Rome, i.e. to use the unifying power of commerce as a tool to bring peace between its members in the wake of World War II. But there are key differences between SAARC and the then EEC (today's European Union), a major one being that political cooperation has been at the heart of the European project from its inception: rooted in ancient times and in a long history, ${ }^{26}$ it found inspiration in the Duc de Sully's 'Grand Design' as early as 1620, gaining further salience after Saint-Simon presented a proposal at the Congress of Vienna (1814-1815) in which he stressed the need to 'unite the peoples of Europe in a single political body while still preserving their individual nationalities' (Chebel d'Appollonia 2002: 180). ${ }^{27}$ The European project eventually materialized through the establishment of a Parliament in the $1950 \mathrm{~s}^{28}$ As far as SAARC is concerned, although the very process of forging a project to overcome a shared history of discord and conflict is in itself an eminently political initiative, there is some ambiguity in the way political cooperation is treated in the objectives and principles of its charter. Indeed, there are only two occurrences of the word 'political' in the charter: one calls for cooperation within the political system of each state, and the other reasserts the respect for the political independence of each state member. Although not surprising given the post-colonial history of the region, composed of new nation-states including two born out of the breaking up of a single entity, it does not contribute to consolidating the idea of South Asia in the absence of a binding political identity. And this not only in the sense of a common representative political body (like a Commission or a Parliament) but also in the sense of a common political culture, as conversely, the diversity of regimes has been a dominant feature in the political landscape of the Subcontinent. This contrasts once again with Europe where a binding ideology defined by Pagden, as 'some kind of republicanism' has existed since early modern Europe (2002:5). Secularism could have been one such common ideology but it has been increasingly undermined throughout the Subcontinent (Jaffrelot \& Mohammad-Arif 2012). To further extend the comparison with Europe, the latter has institutionalized the freedom of movement through the Schengen Agreement (implemented from 1995 onwards), while in South Asia, it is rather the obstruction to movement, through travel restrictions between state members, that has been institutionalized, thereby thwarting any notion of South Asian 'connectivity'.

After this brief survey of top-down constructions of South Asia, both exogenous and endogenous, and their caveats, I shall now take a different lens by turning to a bottom-up perspective, which includes first a description of a shared culture that contributes to everyday constructions of the region and, second, an analysis of ideological constructions. 


\section{A shared culture: everyday constructions of South Asia}

Needless to say, the Subcontinent is characterized by tremendous socio-cultural diversity, which, in the first place, is observed within each country of the region. Yet people of the region share social, cultural, linguistic and religious practices across national boundaries. These two assertions are so true that one could be tempted to use the metaphor of the half-empty glass $v$ s. the half-full glass: either one can see the diversity as too overwhelming to see any relevance in the region as a civilizational entity or one can point out the similitudes and see them as symptomatic of cultural continuities across the Subcontinent. For the sake of remaining coherent with the argument of the construction of South Asia, but also because there are enough elements to support the contention of cultural continuities, be they only 'instinctively, routinely shared' (Vajpeyi 2012), I will choose here the second option. Except for the example of cricket, only commonalities that are specific to the region will be examined here.

Commonalities in social and cultural practices find their roots in centuries-long cultural encounters, ${ }^{29}$ but also in quests for status and power. ${ }^{30}$ Such commonalities are numerous and varied, ranging from marriage customs ${ }^{31}$ to material culture and culinary habits (such as eating with fingers ${ }^{32}$ ). Cultural continuities may not be observed throughout the whole Subcontinent (although there are a few exceptions such as the emblematic shalwar kameez, some common blend of spices, like garam masala, some common dishesnotwithstanding the different recipes-such as kichdi and kheer prepared and consumed from Afghanistan to Sri Lanka ${ }^{33}$ ), but largely cross the national borders between, for instance, both sides of Punjab, Sindh and Rajasthan, West Bengal and Bangladesh, Tamil Nadu and Sri Lanka, and so on. Cultural similarities are thus shared by segments of regional populations. Similitudes are also observed in the social realm as people from the Subcontinent also share analogous hierarchical conceptions of society, with the caste system largely replicated by non-Hindus as its epitome: 'Southasia is a wonderland in which we have managed to introduce caste into all religions, be it Christianity, Buddhism, Jainism or Islam', writes Panneerselvan (2008). ${ }^{34}$

On the religious level, ${ }^{35}$ the situation is peculiar for Hinduism as it is both so consubstantial to the region, and internally so diversified, that there would not be much relevance in pinpointing South Asian specificities across nations. Nonetheless, common practices, related to specific traditions such as Tantric practices and Bhakti, observed across the Subcontinent, could be meaningfully mentioned here. As far as Islam is concerned, similitudes in practices across nations relate both to inclusivist traditions, like Sufism, which, integrating features from other religions (as shown by the dargah-related practices), has spread to the whole Subcontinent from the medieval period and continue to be followed in various forms in the contemporary period; and to more exclusivist traditions, such as the Indian born and flavoured reformist Islam (e.g. Deobandi movement and its affiliate, the Tablighi Jama'at, the Jama'at-i Islami, ${ }^{36}$ etc.), which has expanded to most countries of the Subcontinent, including Afghanistan (as is well known, the Taliban are 'products' of Deobandi seminaries), influencing the socio-religious practices of the followers across the region. So much so that despite the great internal diversity of Islam the phrase 'South Asian Islam' would not be a misnomer as it remains both specific to the region and has spread throughout the Subcontinent. 

strikingly similar, such as the 'dynastic' tradition that has enabled women to occupy the highest position in several countries of the Subcontinent (India, Pakistan, Bangladesh, Sri Lanka), notwithstanding the fact that discrimination against women can reach high levels in these societies (so much so that most countries from the Subcontinent also share an unbalanced sex ratio resulting from female foeticide via sex selective abortions, unequal care provided to boys and girls, and infanticide). More fundamentally, the major communities of the region, be they Hindu, Muslim, Sikh or Christian have historically 'coexisted with contiguous and overlapping, though not assimilable, political ethics' (Bayly 1998: 121) based on a common vision of good government. Chris Bayly (1998: 15-17) demonstrates for instance that although the ethical systems of Hindu and Indo-Muslim traditions did not completely merge, there were similitudes between the principles of government in Hindu classical texts, like the Laws of Manu (ca. $2^{\text {nd }}$ century A.D., see Olivelle 2004: xii-xxiii), and their Indo-Muslim equivalents, such as Abu Fazl's Ain-i-Akbari (1590). In the colonial period, their 'sentiments of attachment [to the patria] and political norms had been homologous and complementary' (Bayly 1998: 115-116).

Borders are among the most emblematic and visible symbols of the delimitations of a nation-state. In that, the Subcontinent represents a real laboratory as political frontiers have been a major, and often tragic, issue in the history of the region. Their crossing represents another form of everyday constructions of South Asia. It can occur on an almost daily basis, as shown by the circulation of Bangladeshi and Nepali workers between India and their home countries, erasing the very idea of nation-bound delimitations. ${ }^{37}$ Beyond physical circulation as such, the Subcontinent is a very interesting case-study of transborder populations that are not only numerous but spread across different regions of this part of the world: Punjabis, Pashtuns, Kashmiris, Baloch, Bengalis, Assamese and so on. Their interest lies not only in the fact that the very existence of a few of these groups contributes to the debate on the question of the geographical extent of South Asia (like the Baloch who live across Pakistan and Iran), but some of these communities (such as the Tamils for instance) also form family networks through matrimonial practices, while others, who are separated by uncrossable boundaries, have recourse to other vectors like poetry to keep the memory alive of their common cultural and historical heritage: in this special issue, Radhika Gupta thus examines through the example of the Baltis of Kargil the circulation of cultural forms between India and Pakistan, 'sustained by shared linguistic and religious histories'. Worth mentioning is also the intriguing phenomenon of chhitmahal, the series of enclaves situated along the India-Bangladesh border, studied by Jason Cons in this special issue: focusing on Dahagram, the largest of these enclaves, Cons emphasises the need to reconceptualize the postcolonial territory of South Asia which, in its present form, does not faithfully reflect the lived realities at the margins, characterized by everyday negotiations that challenge nationalist and communal geographies.

Art is another case in point. Some genres in music and dance (qawwali, bhangra, kathak, bharatanatyam, etc.) have endorsed a pan-South Asian character as they are practiced and appreciated much beyond the national scale. Similarly, a rich literature in vernacular languages, far from being confined to a single region/nation, is part of a poetic and literary culture transcending communities and state boundaries, from Amir Khusrau's iconic poetry and ballads ( $14^{\text {th }}$ century) to the Kabir Panth ( $16^{\text {th }}$ century) and to Waris Shah's Heer Ranjha ${ }^{38}$ (18 $8^{\text {th }}$ century) and Bullhe Shah's poetry. ${ }^{39}$ As Manan Ahmed (2013: 49) 
notes, these narratives and stories 'combine orality, practice and daily rituals where various strands of spiritual knowledge make new forms-deeply-rooted in the local, from Punjab to Awadh to Deccan, to Bengal'. Modern literature also offers scriptural illustrations of a cultural heritage that bind people of the Subcontinent, through their shared appreciation and 'consumption', beyond frontiers. Remarkable examples include Saadat Hasan Manto (1912-1955), one of the iconic writers on Partition whose $100^{\text {th }}$ birth anniversary was celebrated in 2012 in Lahore, Karachi, Bombay and New York ${ }^{40}$; Allama Iqbal (1877-1938), the spiritual father of Pakistan, whose Saare Jahan se Accha Hindustan Hamara is the national marching song for India; Rabindranath Tagore (1861-1941), whose songs have been used as the national anthem in two countries, India and Bangladesh, and have inspired a third one, Sri Lanka's; Kazi Nazrul Islam (1899-1976), the national poet of Bangladesh, who is the only person to appear on the stamps of Bangladesh, India and Pakistan ${ }^{41}$ (Mohaiemen 2012); or Subramania Bharathi, "whom Tamils in India and beyond [i.e. Sri Lanka and the diasporas] continue to look upon as the nationalist bard par excellence' (Mangala-Frost 2006: 150).

In the everyday constructions of South Asia, some platforms operate as cementing vectors between countries of the Subcontinent: Bollywood movies represent an iconic example as they provide a sense of 'community' through the 'formation of a common public that coheres around Bombay cinema' (Ahmed 2012) and a common language that keeps the memory of historical ties vibrant: 'it enables the creation of new cultural referents, provides a common vocabulary, and most crucially, maintains long-standing historical and cultural thematics within living memory' (Ahmed 2012). As Manan Ahmed (2013: 51) emphasizes, the shared appreciation of Bollywood and its songs takes its roots in a common regional imagination of love and friendship dating back to the epics of the $17^{\text {th }}$ century. Bollywood also offers a platform for interaction among artists not only across regions and religions but increasingly across borders as well. ${ }^{42}$ Songs are particularly reflective of this close interconnectedness beyond borders: songs inspired by Faiz Ahmed Faiz's poetry are thus part of the repertoires of both Indian and Pakistani singers.

Some Bollywood movies directly address the issue of cross-border relations (particularly between India and Pakistan): they either demonize the Other ${ }^{43}$-but, as Manan Ahmed (2012) states, demonization still 'showcases the capacity to imagine the Other'-or they find ways, sometimes amusing ones, to highlight commonalities beyond borders and/or try to erase lines of difference. ${ }^{44}$ This suggests that temporalities are also important in the way South Asia is constructed, as discourses about the Other are particularly volatile, shifting, almost overnight, from bhai bhai (such as during the 'reconciliation' period between India and Pakistan in 2004-2008) to sheer antagonism and vice-versa. However, whereas tense relationships between countries used to manifest themselves over the ways the 'Other' was portrayed in Bollywood movies till the early 2000s, economic considerations have since come to prevail over 'parochial nationalism': the different South Asian countries and the respective diasporas of each nation of the Subcontinent represent such huge markets that the demonization of the Other, even during periods of tension between South Asian countries, might lead to backlash in financial terms. Beyond the issue of imagining the Other, economic benefits at large are a main driving force behind the circulation of cultural products (essentially from India to other South Asian countries but reverse circulations also occur ${ }^{45}$ ) and participate in their own ways in the construction of ideas of South Asia. ${ }^{46}$ 
31 In popular perceptions, cricket is, along with Bollywood, the other binding vector between people of the region. While this can hardly be denied in terms of the comparable craze it generates among people in most South Asian countries, cricket is a double-edged sword: the similitude in emotions is observed not only in the sheer common fun of watching a match but also in the nationalist passion aroused by the game. These nationalist feelings may come along with an open antagonism against the rival South Asian team when two teams from the Subcontinent meet: as if they were fighting proxy wars (except in Test matches ${ }^{47}$ ). But just like the demonization in Bollywood movies implies a capacity to imagine the Other, negative emotions, such as antagonism, expressed during cricket matches or on other such occasions, also participate in their own ways, in making the regional idea exist as they take their roots in a shared history of conflicts.

In sum, looking at cultural continuities not only contributes to the notion of a South Asian cultural space but these continuities are also related to practices that generate everyday constructions of South Asia. Moreover, they provide to the builders of South Asia from below, whose role will be addressed in the following section, the material and symbolic resources on which to construct their imagination of the region as an entity.

\section{'South Asia' Revisited: (Re)Constructing the region from below}

\section{'South Asia', a binding name and notion for social struggles}

While the description of historical and cultural commonalities may convey anthropological substance to the idea of South Asia at the level of ground reality, some individuals and groups do not see 'South Asia' as a mere geographical expression or as an emotionally-cum-commercially productive platform of interaction. Rather in the wake of tense relations between the countries of the region, they deliberately engage in discourses about South Asia as an entity (as loosely and heterogeneously as it might be defined). This is illustrated, for instance, in the declaration of the 'People's SAARC', a forum created in the mid-1990s, composed of a network of organizations from regional 'civil societies' (peasant movements, trade unions, women's and feminist groups, anticaste movements and so on):

We, the people of South Asia, not only share a contiguous geographical space but also a social and cultural history that shapes our life styles, belief systems, cultural particularities, material practices and social relationships. Our natural environments are related, interdependent, and form elements of a common ecosystem. There is a similarity in our life practices. Our belief systems and cultural practices influence/complement each other, thus exhibiting distinct similarities. On the other hand, the unique diversity of our region in all aspects has enriched the common heritage, and we celebrate a sustained history of mutual respect for one another. ${ }^{48}$

In a similar vein, Aunohita Mojumdar (2013), a journalist from the team of the magazine Himal Southasian, one of the major platforms, as mentioned before, for the construction of ideas of South Asia from below, writes:

We share rivers, forests and monsoon patterns and are impacted by deforestation, landslides and flooding, but lack awareness about what exists across the border. We have intricate trade relations that help and curb the transit of goods, but are 
completely ignorant about the economies of our neighbours. We have massive migration within the region but know little about the peoples of other countries. We have a large portion of our region beset by conflict but little more than a jingoistic appreciation of these. The information and awareness that is needed in the region in order to foster tolerance and build the idea of a cooperative 'southasianess' is missing. promotion of cross-border practices along with appeals for regional cooperation at the grassroots level, as an alternative to compensate for the perceived failures of top-down initiatives (by SAARC in particular). In their view, the deflation of political tensions and the promotion of peace and demilitarization are closely interlinked with the social, economic and political advancement of the region. These groups occasionally undertake collective mobilization through the Internet or regional meetings. They take place around a vast array of issues of common concern, across borders, such as democracy, globalization, food sovereignty, debt cancellation, trafficking of women and children for prostitution, gender-based violence, caste discrimination, religious extremism and communalism, environment, basic health needs, etc. ${ }^{49}$ Admittedly, these initiatives have been largely hampered by cross-border travel restrictions (Ramachandran 2012). Yet these discourses and practices remain essential elements in the creation of emerging 'ideas of South Asia' from below.

In migration, ideas about South Asia have surfaced as a result of two processes. First is the awareness of cultural and social commonalities resulting not only from direct interactions with people from different countries of the Subcontinent, but also from categorizations imposed by host-societies on migrants from the region (census, university admission forms, the names of research centres and so on). Second are "proactive' constructions of South Asia, enounced in discourses and put into practice through the establishment of organizations, in North America in particular, that are deliberately named South Asian, as a political statement. As a matter of fact, more than 'South Asia', the term 'South Asian' has been increasingly meaningful in the diaspora, as a means of self-identification (although, as Anouck Carsignol indicates in this special issue, competing names, such as desi, have also emerged). Beyond the politics of naming, which can also take place in constructions from below, interlinkages are established, as Carsignol shows, between constructions of South Asia that are mainly relevant for the Subcontinent (peace, denuclearization, development, etc.) and those that are more specific to the diasporic context (common concern over stigmatization, racism and marginalization experienced in host-societies).

Whether in the Subcontinent or in diaspora, these grassroots activists thus essentially see mobilizations around the notion of South Asia as the most efficient way of combating all kinds of social and political evils but without necessarily 'thinking' the category 'South Asia as such.

\section{Ideologizing South Asia}

Another group, which connects the construction of South Asia with social struggles and which includes people hailing mostly, if not from the elite, at least from educated backgrounds, goes a step further by addressing the category as such, and by doing so in a way that ideologizes 'South Asia'. This is not to say that other constructions of South Asia (strategic ones for instance) are deprived of ideology, far from it; this is not to say either 
that imaginations of South Asia can only take form in the minds of the elites. But we do observe specific forms of endogenous 'ideologization' from below initiated by people comprising mainly intellectuals (academics, journalists, writers and artists) based in the Subcontinent or in diaspora, particularly in Anglo-Saxon countries. Their major mode of expression is online media (blogs, journals, listservs). The names of the websites are in themselves revealing, and partake of a politics of naming from below: Himal Southasian (Mani Kanak Dixit, the editor and one of the leading and most committed supporters of the idea of South Asia as an entity, explains, in this special issue, how the name of his magazine was changed from Himal to Himal Southasian in a single word in order to indigenize a name given by outsiders), ${ }^{50}$ One South Asia, TheSouthAsianIdea Weblog, South Asian Citizens Web, TVSouthasia, PanosSouthasia, and so on. It is as if the questioning of the existing borders represented their very raison d'être, and as if there was a rethinking of the region along pre-Partition borders. This can also be inferred for instance from the title of an issue mentioned above and published in the journal seminar in April 2012: A country of our own: A Symposium on Re-imagining South Asia. The issue gathered several academics from India, Pakistan and Bangladesh, with the following objective stated by Ananya Vajpeyi (2012):

We meant to provoke an audacious, imaginative projection of South Asia that actively militates against the pain, loss and grief of our burdened and compromised histories, that restores and heals, that allows Hindus-Muslims-Sikhs-IndiansPakistanis-Bangladeshis or whatever other categories of people to come back into a degree of intimacy, familiarity, trust and reconciliation with one another. We tried to say: let's dream of a history not as a series of wounds, but as a set of limitless possibilities for flourishing, for dialogue, and for human intertwining. [...] Our nation-driven geopolitical and historical predicaments are ridiculous and untenable in their own ways, as we are all more than aware. We were willing to entertain the wildest imaginings for a better South Asia-truly a country of our own.

These ideological constructions of South Asia, challenging existing borders, raise a series of questions. The first set is related to the mental geography of the supporters of the idea of South Asia. ${ }^{51}$ Are ideas of South Asia confined to India, Pakistan and Bangladesh, leaving aside other countries which were not part of British India, and which hence did not go through the painful process and experience of partitions? The idea of a reunification, different from that of an ex-nihilo unification (such as the project of the European Union), is indeed a major aspect of these constructions of South Asia, although its supporters do not necessarily dream of a territorial reunification but rather of an 'ideational' one, to quote from Tagore..$^{52}$ The issue of Seminar mentioned above partakes of this logic as it only addresses questions related to India, Pakistan and Bangladesh.

However the example of Himal Southasian, based in Nepal, which regularly gathers contributors from all over the Subcontinent, and contains articles about all the States including Bhutan, the Maldives and Afghanistan, implies that some constructions of South Asia from below are inclusive of other countries of the region as well. For some, Burma and Tibet are also thought of as part of the entity (see Dixit in this special issue).

These multiple and overlapping constructions of South Asia interrogate once again the geographical delimitations of the notion as it may comprise not only the countries that once were one but other states as well, including those which do not necessarily share many cultural similarities with the core countries, such as Burma, and this in the name of a shared colonial past. Conversely, cultural definitions can take precedence over geographical ones when the notion is applied to people living outside the physical limits 
of the Subcontinent, i.e. diasporas. In this special issue, Claude Markovits shows how Gandhi (1869-1948) constructed a notion of India (and not of South Asia, of course, as it would have been anachronistic), when he was in South Africa, that enabled him to inhabit both spaces at the same time, thereby mentally blurring the boundaries of the Subcontinent.

42 A second set of questions is linked to the underlying ideological principles in this (re)imagination of the region, beyond the overlapping layers of construction of South Asia. Are these activists primarily rethinking the past by interrogating the frontiers put into place at the time of the Partition? Or are they imagining a different future? The combination of emotions, such as nostalgia and hope, perceptible in their writings, suggests an interdependency between both, and resonates with discourses on Europe. Chebel d'Appollonia thus writes: 'Even today the champions of the Maastricht Treaty justify their position in the name of a reconstructed past and an idealized future' (2002: 179).

What kind of political principle is pervading the goals and initiatives of the activists? The answers are not easy to provide as we lack thorough research on these questions. Moreover, the phenomenon is fairly difficult to analyze as it is not embodied in an organized movement; neither does it have ideologues formulating ideas or projects for the region comparable to the European philosophers or political writers who laid down the ideological grounding for the construction of Europe..$^{53}$

Nevertheless, a number of points can be inferred from the activists' writings. First, they do not reject the nation-state, far from it, most subscribe to the basic principle that there should be no obliteration of national identities:

In the new and effective regionalism that we seek, the idea is not to supplant the nation state but to complement it by giving the people and the polities an additional dimension to their identities-a dimension that is both historical and psychologically energizing (Himal Southasian 2011).

It is worth consideration that these views are reminiscent of the European nationalism from the Enlightenment to 1848, based on the perception that 'there was [...] no contradiction between Europeanism and national sentiments when these sentiments were not exclusive' (Fontana 2002: 174).

Second, they seem to be sharing a sense of an imagined community bound by a specific 'sensibility'. It is defined as follows in Himal Southasian:

If Southasian-ness is a sensibility, then anyone can be a Southasian. The requirement is having respect for the history of the Subcontinent and empathy for its people. You can be a native or a non-native. Of course it helps to be born in any one of the countries of the region, but you can also be a naturalised Southasian due to the empathy you develop for this region and its populace (Dixit 2011b).

47 The concept of a South Asian sensibility, which has given its name to a book edited by Kanak Mani Dixit that compiles some of Himal Southasian's most significant articles, rests upon the notion of the experience of feeling borrowed from T.S. Eliot. Commenting on the 'Bengali sensibility' perceptible in Amit Chaudhuri's (b. 1962) works, Arun Kumar Yadav (2012) defines regional sensibility in ways that could be applied to South Asia as well:

In the 20th century the term 'regional sensibility' has been used to denote an intellectual and emotional perceptiveness, the sense employed by T.S. Eliot when he described the 'Dissociation of Sensibility.' Regional sensibility means characteristic ways of responding in perception, thought, and feeling to experience. It emphasizes the setting, speech, social structure and customs of a particular 
locality. It manifests not only the local colour but also an important condition affecting the temperament of the characters and their ways of thinking, feeling and interacting. [...] Thus, regional sensibility means the cultural and moral attitude of people, their overall characters, and customs and the way of life.

In Himal Southasian's text (Dixit 2011b), this sensibility, which embraces people across nations, is interlinked with empathy, seen as the core emotion to build solidarity in the region across nations, or, in other words, to build regionalism. Needless to say, since the need for South Asia as a category partly came up as a result of a violent history marked by several partitions, a vast array of emotions, displayed like a Janus face (hate vs. love, fear vs. hope, etc.), has been playing a dominant role in the constructions and deconstructions of the region. But some specific emotions can be mobilized in order to participate in the more deliberate construction of the region, such as empathy here. In another text published in a recent book compiling several articles, mostly oriented towards the path the region will take in the next 50 years, Dixit (2013: 29-30), defending the idea of regionalism, thus writes:

At the start of the second decade of the twentieth century, we are still in the process of evolving as Indians, Pakistanis, Bangladeshis and Sri Lankans. This is of course not a bad thing, but in acquiring the exclusive identity of the nation-state we have lost touch with the overarching quality of empathy - external and internal. This has left us with a South Asia battered with animosities, where a united front has failed to develop to check the blundering or the malevolent overseas players. These animosities have, most importantly, affected economic advancement in the poorest, most densely populated parts of the region. [...] Ultranationalism is what renders heartless when horrors happen across the border, generating an empathy deficit that prevents a response when floods or earthquakes ravage contiguous regions.

49 It is worth consideration that the author does not frame the empathy leading to solidarity in 'humanistic' or romantic terms but, as noted above, in the language of mutual interests with the pragmatic recognition of the economic advantages that solidarity, via empathy, could bring to the entire region.

\section{A post-colonial patriotism?}

In order to frame this 'sensibility' in the language of social sciences, we may formulate here a few hypotheses by briefly drawing comparisons with, on the one hand, processes that have been historically at play in the Subcontinent, and on the other, with similar projects that have emerged in other regions of the world, such as Europe. Is this a new form of nationalism without nation-states? Or, as embryonic as it might be, is this a new kind of post-colonial patriotism presenting some similarities with the patriotism of the pre-colonial past which went 'beyond simple chauvinism' and was characterized by 'cultural mixing and the forging of hybrid identities' (Bayly 1998: 54-55)? In keeping with Bayly's conceptualization of pre-colonial patriotism, it is as if South Asia had replaced 'Hindustan', 'as a value-laden word which afforded an ideological symbol and a historical memory [...]' (Bayly 1998: 44; see also in this special issue Kaviraj, who examines the notion of South Asia from a 'vestigial pre-modern' perspective). In this 'watanization'54 process, the scale has changed, encompassing a vast region with fluid geographical boundaries.

51 The mention in Dixit's text of 'overseas players' is also worth noticing as in the formation of patriotism the reference to the 'Other' or to 'Others' is usually energizing. ${ }^{55}$ However, 
there is no formation of a common outside 'enemy': it can be the West for some and/or at times, China for others and/or at other times, with a different rhetoric accordingly: resistance to domination (anti-imperialism has replaced anti-colonialism, except that 'the outside enemy' remains the same) vs. collaboration-cum-competition for domination in the larger region (Asia).

But more significant is the fact that in this 'patriotism', it is as if South Asians were imagined as a single community bound by a shared morality (combining, broadlyspeaking, pacifism and secularism) and a composite culture overriding potentially divisive affiliations like religion or caste and stemming from the idea that 'civilizations don't have to be built on a single principle' (Khilnani 2004). This is reminiscent of Nehru's views on composite culture:

By this [composite culture] he meant the continual presence and processes of reciprocity; mutual sharing and overlap of cultural practices; styles of life; a technological and economic worldview of the relationship between nature and culture; shared practices of economy and technology; values and belief systems cutting across the divides of space; and religious belief systems and specificities of community differentiations. (Singh 2008: 195)

So much so that this may suggest a conflation between the idea of India and the idea of South Asia. In any case, the salience of the notion of composite culture can also be inferred by the type of 'cultural heroes' that the activists mobilize or refer to: Ghalib (1797-1869), Tagore, or writers from the Progressive Writers Movement such as Faiz Ahmad Faiz (1911-1984). ${ }^{56}$ However, while these poets used vernacular languages as vehicles of expression, the language that the activists mostly use to convey their ideas about South Asia is English. Unlike Hindustani, English may not be endorsed with an ideological meaning (see Bayly 1998), and has a function of neutrality in a region characterized by a huge diversity of languages, which even compete at times. Yet English is 'the link language', to borrow from Bayly's analysis of Hindustani (1998: 43), which allows cross-border and cross-region dialogues and interactions, with the difference, however, that there is no conflation here between language and ethnicity, as there might have been at some point between Hindustani language and 'a latent Hindustani identity' (Bayly 1998: 40). But it does remain that if the idea of South Asia has a language, it is probably English, all the more so as English websites represent a major medium of communication for the activists. This implies that such constructions from below remain confined to elite circles. As if they were forming an avant-gardist enlightened community of postcolonial intellectuals, journalists and artists, based in the Subcontinent or in diaspora, and united by the basic principle of believing that the region, loosely defined as per one's mental geography, forms an entity ('Read against this long history-of intersectarian, interreligious politics, rooted languages, nested stories, entangled everyday lives-civilizational difference is impossible to argue,' writes Manan Ahmad (2013:50)), while acknowledging altogether the variety of the peoples, histories and cultures that coexist in the Subcontinent: 'unity in diversity' in other words, but at a larger scale than pre-colonial and post-colonial India. It is worth consideration that, with all the nuances such an assertion requires given both the difference of contexts and influence at this stage, this phenomenon is somewhat reminiscent of the République des Lettres in Europe, composed of 'educated aristocrats, writers and scientists' (Fontana 2002: 118-119), who emerged as a proto-European community during the Enlightenment period and laid the intellectual foundations for the future European Union. 
the ideas about South Asia: top-down and bottom-up, exogenous and endogenous, everyday ones and 'deliberate' ones. The various constructions show that the notion of South Asia refers to two different logics depending on the actors and the context in which they use it: one is the formation of a region, the other is the emergence of regionalism. Exogenous constructions mostly lead to the creation of a region, with varying, and sometimes overlapping, objectives depending on the actors involved, such as knowledge production or mapping of the world driven by strategic concerns. Endogenous constructions, whether top-down or bottom-up, tend to go a step further by leading to the invention of a multi-faceted regionalism. While peace represents the basic common goal of the actors involved in such constructions, other purposes come into play, such as the social, economic and cultural development of the region, the interlinking of South Asia as a category symbolizing cultural entity, with particular struggles in both homesocieties and in the diaspora. In between these two lie non-deliberate practices, which also contribute to the construction of the region and provide the 'builders' with the necessary historical and cultural resources to promote regionalism. In the process, there seems to be a close inter-connection between regionalism and creative forms of patriotism, the latter ideologically nurturing the former.

It is also worth consideration that if the perceptions and the subsequent debates and stakes about South Asia as a category may compete with each other (strategic designs of Western policy-makers vs. anti-imperialist discourses of activists from the Subcontinent), they can also overlap: both academia and grassroots activists can share the characteristic

South Asia Multidisciplinary Academic Journal, 10 | 2014 
of viewing South Asia through the lens of a civilizational entity, except that the former submits the idea for debate, while the latter may endorse it without much questioning. International organizations, like the UN, may not be particularly concerned with the debates over whether the region represents a civilizational entity, but they can share common goals with grassroots activists, such as the promotion of peace in the region. Bollywood, for its part, is not primarily bothered with the civilizational debates, neither is it with peace as the ultimate goal in the region, but takes advantage of cultural commonalities between the countries of the region to attract a larger market. These multiple and multi-layered constructions lead to the polysemy of the word and the concept. As Hasan Altaf (2012) notes:

South Asia, like any other such grandiose idea ('Islam', 'America', 'Europe', take your pick), is not static, an object to be passed from parent to child, like a jadanagam ${ }^{58}-$ it's something that we make, something that we create and modify and reshape.

Beyond the multiplicity of constructions and meanings of South Asia, the very notion can be called into question, highlighting a number of stakes and underpinning debates, some covered in this introduction, some in the papers and some others that have not been dealt with in this special issue. As in a mirror game, counter-arguments are used by multiple actors invoking various reasons: socio-cultural (the notion does not reflect and leave much space to the strong heterogeneity of the region-an argument also used by some 'progressists', see Carsignol in this special issue-; it can be perceived as an attempt at reviving British Empire (see Spencer in this special issue); economic (e.g. if the notion is correlated to the idea of regionalism, it is eschewed by the Indian middle-classes as they do not see any benefit in helping the 'impoverished neighbourhood'59); political (South Asia is another word for India or the notion only addresses the relationships between India and Pakistan); scientific (critical vision of the very concept of area studies); essentialist (reluctance to see the region as a civilizational entity, shared by a section of the so-called Orientalists, the supporters of the two-nation theory, the defenders of Hindutva, and stemming from the belief that Hinduism and Islam form two incompatible civilizations). It should be noted however that the detractors of the notion of South Asia as a 'coherent' region may not necessarily oppose South Asia as a category defining regionalism: the academic critics of area studies, and hence of South Asia as a (well)delineated region, may not for instance object to regionalism as such, if understood as a political project designed to ensure peaceful relations between the countries of the region and to contribute to its socio-economic development.

These construction and deconstruction processes have in turn implications for South Asia as a name, calling into question three related criticisms. One is that it is an empty name. While this assertion cannot be fully refuted, constructions from below show that the name is closely associated with ideas of pacific coexistence, mutual tolerance, composite culture, etc. Two is that the name is only politically correct. Again, this statement cannot be totally challenged as the word does have a 'neutral' value since, as mentioned above, it does not include any of the names of the countries of the region, as opposed to 'Indian Subcontinent'. However, not only does the political contestation it faces show that it cannot be only understood as a politically correct word, but the word has been assigned political significance as it has been ideologized by activists in home-societies and in the diaspora. Three is that 'South Asia' is interchangeable' with 'Indian Subcontinent'. This assertion raises at least two problems: one is directly related to the first point, i.e. that 'Indian Subcontinent' is politically and historically loaded; the other is more 
geographical: the notion of 'Subcontinent' technically excludes islands (Sri Lanka and Maldives). It could also be worth considering that the word 'Asia' in 'South Asia' enlarges the horizon, in comparison with 'Indian Subcontinent', as it nominally puts the region in a larger continent. In return, it may contribute to 'fluidizing' boundaries, building bridges with Southeast Asia, West Asia or Central Asia, and, in the process, more easily accommodate 'margin areas' like the Northeast or Afghanistan.

\section{BIBLIOGRAPHY}

Ahmed, Manan (2012) 'A Conversation' [with Rohit Chopra \& Aswin Punathambekar] in Seminar: A Country of our Own: A Symposium on Re-Imagining South Asia, 632, April.

Ahmed, Manan (2013) 'Future's Past' in Adil Najam \& Moeed Yusuf (eds.), South Asia 2060: Envisioning Regional Futures, London: Anthem Press, pp. 46-54.

Ali, Tariq (2006) ‘South Asia Needs a Southasian Union?', Interview by Subindra Bogati, Himal Southasian, January, URL: http://old.himalmag.com/component/content/article/1636-.html.

Altaf, Hasan (2012) 'Brown as the Mouths of River', Seminar: A Country of our Own: A Symposium on Re-Imagining South Asia, 632, April, URL: http://www.india-

seminar.com/2012/632/632_hasan_altaf.htm.

Appiah, Kwame Anthony (1997) 'The Cosmopolitan Patriot', Critical Inquiry, 23(3), Spring, pp. 617-39.

Barrow, Ian J. (2003) 'From Hindustan to India: Naming Change in Changing Names', South Asia: Journal of South Asian Studies, 26(1), pp. 37-49.

Bayly, C.A. (1998) Origins of Nationality in South Asia: Patriotism and Ethical Government in the Making of Modern India, Delhi: Oxford University Press.

Bleackley, Horace (1928) Tour in Southern Asia: Indo-China, Malaya, Sumatra and Ceylon, 1925-1926, London: John Lane.

Bozec, Géraldine (2010) 'L’Europe au tableau noir: comment les instituteurs français enseignentils l'Union européenne aujourd'hui?', Politique européenne, 30(1), pp. 153-86.

Chatterjee, Partha (2008) 'Democratic Enlightenment and Cultural Production', Himal Southasian, August, URL: http://old.himalmag.com/component/content/article/842-.html.

Chebel d'Appollonia, Ariane (2002) 'European Nationalism and European Union' in Anthony Pagden (ed.) The Idea of Europe: From Antiquity to the European Union, Cambridge: Cambridge University Press, pp. 171-90.

Devji, Faisal (2013) Muslim Zion: Pakistan as a Political Idea, Harvard: Harvard University Press. Dirks, Nicholas (2004) 'South Asian Studies: Futures Past' in David Szanton (ed.), The Politics of Knowledge: Area Studies and the Disciplines, Berkeley: University of California Press, pp. 341-85. Dixit, Kanak Mani (2004) 'South Asia to Southasia', Himal Southasian, January, URL: http:// old.himalmag.com/component/content/article/1709-South-Asia-to-Southasia.html. 
Dixit, Kanak Mani (2011a)'The Discovery of Southasia', Himal Southasian, March, URL: http:// old.himalmag.com/component/content/article/4305-the-discovery-of-southasia.html.

Dixit, Kanak Mani (2011b)'The Occidental Southasian', Himal Southasian, July, URL: http:// old.himalmag.com/component/content/article/4519-the-occidental-southasian.html.

Dixit, Kanak Mani (2012) The Southasian Sensibility: A Himal Reader, New Delhi: Sage Publications.

Dixit, Kanak Mani (2013), 'Federalism on the Road: Region and Regionalism', in Adil Najam \& Moeed Yusuf (eds.), South Asia 2060: Envisioning Regional Futures, London: Anthem Press, pp. 29-37.

Duchesne, Sophie; Haegel, Florence; Frazer, Elizabeth; Van Ingelgom, Virginie; Garcia, Guillaume; Frognier, André-Paul (2010) 'Europe between Integration and Globalisation: Social Differences and National Frames in the Analysis of Focus Groups Conducted in France, Francophone Belgium and the United Kingdom', Politique européenne, 30(1), pp. 67-105.

Emmerson, Donald K. (1984) 'Southeast Asia': What's in a Name?', Journal of Southeast Asian Studies, 15(1), March, pp. 1-21.

Favelle, Adrian (2010) 'European Identity and European Citizenship in three 'Eurocities': A Sociological Approach to the European Union', Politique européenne, 30(1), pp. 187-224.

Fontana, Biancamaria (2002) 'The Napoleonic Empire and the Europe of Nations', in Anthony Pagden (ed.), The Idea of Europe: From Antiquity to the European Union, Cambridge: Cambridge University Press, pp. 116-28.

Gary, Romain (1965) Pour Sganarelle, Paris: Gallimard.

Gellner, David (ed.) (2013) Borderland Lives in Northern South Asia, Duke: Duke University Press. Green, Nile (2011) 'The Trans-border Traffic of Afghan Modernism: Afghanistan and the Indian 'Urdusphere”, Comparative Studies in Society and History, 53(3), pp. 479-508.

Himal Southasian (Editorial) (2011) 'Southasian Elephant', December, URL: http:// old.himalmag.com/himal-feed/58/4825-southasian-elephant.html.

Jaffrelot, Christophe; Mohammad-Arif, Aminah (eds.) (2012) Politique et religions en Asie du Sud: le sécularisme dans tous ses états ?, Collection Purushartha, 30, Paris: Editions de l'EHESS.

Jalal, Ayesha; Seal, Anil (1981) 'Alternative to Partition: Muslim Politics between the Wars', Modern Asian Studies, 15(3), pp. 415-54.

Jalal, Ayesha (2001) Self and Sovereignty: Individual and Community in South Asian Islam since 1850, New Delhi: Oxford University Press.

Kesavan Mukul (2008) 'Against South Asia', Himal Southasian, August, URL: http:// old.himalmag.com/component/content/article/795-against-southasia.html.

Khilnani, Sunil (1997) The Idea of India, New York: Farrar Strauss Giroux.

Khilnani, Sunil (2004) 'Branding India', Seminar: India 2003, 533, January, URL: http://www.indiaseminar.com/2004/533/533\%20sunil\%20khilnani.html.

Laurens, Henry (2013), 'La notion de Moyen-Orient', an interview by Allan Kaval, Les clés du Moyen-Orient, 9 January, URL: http://www.lesclesdumoyenorient.com/Entretien-avec-HenryLaurens-La.html.

Mangala-Frost, Christine (2006) 'Bhakti and Nationalism in the Poetry of Subramania Bharati', Hindu Studies, 10, pp. 150-66. 
Matringe, Denis (1992) 'Krsnaite and Nath elements in the poetry of the eighteenth-century Panjabi Sufi Bullhe 'Sah', in Ronald S. McGregor (ed.), Devotional Literature in South Asia, Cambridge: Cambridge University Press.

Mehta, Vinod (2008) ‘What neighbourhood?', Himal Southasian, August, URL: http:// old.himalmag.com/component/content/article/817-what-neighbourhood.html.

Michaud, Jean (2010) 'Zomia and Beyond', Journal of Global History, 5, pp. 187-214.

Mir, Farina (2010) The Social Space of Language: Vernacular Culture in British Colonial Punjab, Berkeley: University of California Press.

Mohaiemen, Naeem (2012) 'Kazi in Nomansland', Seminar: A Country of our Own: A Symposium on ReImagining South Asia, 632, April, URL: http://www.indiaseminar.com/2012/632/632_naeem_mohaiemen.htm.

Mojumdar, Aunohita (2013) 'Himal Southasian', The Newsletter, International Institute for Asian Studies, 65, Autumn, p. 47.

Najam, Adil; Yusuf, Moeed (eds.) (2013) South Asia 2060: Envisioning Regional Futures, London: Anthem Press.

Olivelle, Patrick (2004) 'Introduction', in The Law Code of Manu: A New Translation by Patrick Olivelle, New York: Oxford University Press.

Pagden, Anthony (ed.) (2002) The Idea of Europe: From Antiquity to the European Union, Cambridge: Cambridge University Press.

Panneerselvan, A.S. (2008) ‘Being South-Southasian', Himal Southasian, August, URL: http:// old.himalmag.com/component/content/article/794-being-south-southasian.html.

Ramachandran, Sudha (2012) 'People's SAARC: Building a South Asian Identity from Below', paper presented at the conference The Idea of South Asia, on the occasion of the $15^{\text {th }}$ CEIAS' Annual Day, 13 November.

Rimal, Gauri Nath (2011) “Bol’! The Nepali People!', Himal Southasian, January, URL: http:// old.himalmag.com/component/content/article/3538-bol-the-nepali-people.html.

Singh, Yogendra (2008) 'Composite Culture, Community and Identity: Interface for Social Change in India', in Bipan Chandra \& Sucheta Mahajan (eds.), Composite Culture in a Multicultural Society, New Delhi, Pearsons Education.

Sivasundaram, Sujit (2013) Islanded: Britain, Sri Lanka, and the Bounds of an Indian Ocean Colony, Chicago: the University of Chicago Press.

Subrahmanyam, Sanjay (1997) 'Connected Histories: Notes Towards a Reconfiguration of Early Modern Eurasia', Modern Asian Studies, 31(3), pp. 735-62.

Szanton, David L. (ed.) (2004) The Politics of Knowledge: Area Studies and the Disciplines, Berkeley/Los Angeles, University of California Press.

Talbot, Ian (1998) Pakistan: A Modern History, New York: St Martin's Press.

Tiwari, Sudha (2013) 'Memories of Partition: Revisiting Saadat Hasan Manto', Economic \& Political Weekly, 48(25), 22 June.

United States Government Printing Office (1959) The Subcontinent of South Asia: Afghanistan, Ceylon, India, Nepal and Pakistan, Superintendent of Documents, United States Department of State: Public Services Division. 
Vajpeyi, Ananya (2012) 'The Problem', Seminar: A Country of our Own: A Symposium on Re-Imagining South Asia, 632, April, URL: http://www.india-seminar.com/2012/632/632_the_problem.htm.

van Schendel (2002) 'Geographies of Knowing, Geographies of Ignorance: Jumping Scale in Southeast Asia', Environment and Planning D: Society and Space, 20(6), pp. 647-68.

Yadav, Arun Kumar (2012) 'Regional Sensibility in Novels of Amit Chaudhuri', Asian Literary Supplement, July-August.

Zaidi, Akbar (2009) 'Pakistan: A Year of Moving On', Economic \& Political Weekly, 44(1), 3 January, pp. 8-9.

\section{NOTES}

1. Although 'Enchanting Abstraction' is first and foremost the name of a painting by Yoshida Shizuko, I am borrowing the phrase from the British born Ghanaian philosopher and cultural thinker, Kwame Appiah (1997: 617), who used it to describe the relation of his father to Africa.

2. My grateful thanks to Gilles Dorronsoro, Grégoire Schlemmer and Sanjay Subrahmanyan for their useful comments on this project at an earlier stage and to the anonymous reviewers of my paper. My heartiest gratitude also goes to the SAMAJ team.

3. The Directorial Committee (2010-2013) was composed of Blandine Ripert, Loraine Kennedy, Stéphanie Tawa Lama-Rewal and Aminah Mohammad-Arif.

4. This curiosity led to the organization of a conference at the CEIAS in November 2012 on 'The Idea of South Asia', bringing together scholars from various disciplines. This special issue of SAMAJ is the result of those reflections, which Blandine Ripert and I have extended by soliciting other scholars to address issues not covered in the conference.

5. The region primarily refers to India, Pakistan, Bangladesh, Sri Lanka, Nepal, Bhutan, the Maldives, as per the definition of the SAARC (South Asia Association for Regional Cooperation), which has however included Afghanistan lately (2007) among its members. See below.

6. This comparison could have been stimulating given the similar gap between state spaces and cultural continuities across frontiers, resulting from colonization.

7. This book is mentioned in Emmerson's article (1984).

8. See Szanton (2004: 1-33).

9. As a specialist of Sanskrit studies, Norman Brown was above all a classical scholar, but he was interested in contemporary issues as well, including political developments in the Subcontinent. See Dirks (2003).

10. United States Government Printing Office (1959).

11. For example, the Asian Relations Conference in Delhi in April 1947, the Baguio Conference in the Philippines in May 1950, the Colombo Powers Conference in April 1954, etc.

12. Although the construction of the campus will start in 2014, the university has started offering courses to students since August 2010 in a temporary campus in Chanakyapuri. Degrees and certificates delivered by the SAU are recognized by the University Grants Commission in India and by other SAARC member states.

13. See http://sau.ac.in/downloads/accredit/Inter-Governmental-Agreement.pdf.

14. Point 2 reads: 'Conscious that in an increasingly interdependent world, the objectives of peace, freedom, social justice and economic prosperity are best achieved in the SOUTH ASIAN region by fostering mutual understanding, good neighbourly relations and meaningful cooperation among the Member States which are bound by ties of history and culture'. See: http://www.saarc-sec.org/SAARC-Charter/5/. 
15. She was the 'daughter of Agenor, King of the city of Tyre, on the coast of Sidon [...] carried off by Zeus and transformed into a white bull' (Pagden 2002: 34). Interestingly, Pagden stresses that there is mundane version of the story, suggested by Herodotus, whereby Europa was an Asian woman abducted by Cretan merchants, this implying that 'not only were the origins of Europe non-European, but that no one could establish with any precision where Europe stopped and Asia and Africa began' (Pagden 2002: 34-6).

16. Hindustan had two overlapping meanings, one was the equivalent of all-India (Sara Hindustan), the other was restricted to the heartland of Hindustani-speaking North India. But in the $18^{\text {th }}$ century, Hindustani culture expanded to the south so much so that 'it was now possible to identify the cultural term Hindustan with the greater part of the Subcontinent' (Bayly 1998: 43).

17. See also Szanton (2004). We may also mention the (unpublished) debates about area studies that took place at the EHESS, in 2002 and 2003, in which two of the contributors to this special issue, Claude Markovits and Sanjay Subrahmanyam, participated.

18. About the different ways of spelling 'Southeast Asia', see Emerson (1984).

19. It was however during World War II that the word 'Southeast Asia' became popular (Emmerson 1984). According to Emmerson (1984: 5), although the actual identity of the name's inventor is not known for sure, the first use of the word 'Southeast Asia' may have occurred in 1839, the year the travelogue of an American cleric, Howard Malcolm, was published under the title Travels in South Eastern Asia, but Malcolm himself may not have used the word or explain it. As for its scholarly usage, it may date back to 1847 when a British anthropologist, J.R. Logan, inaugurated it in a series of articles published in The Journal of the Indian Archipelago and Eastern Asia.

20. Zomia is a term coined by van Schendel in 2002. He challenged the boundaries as fixed by 'standard' Area Studies, and proposed an alternative entity that initially encompassed the Himalayan Range, the Tibetan Plateau and the Southeast Asian highlands. In 2007, he extended the zone northward and westward to include southern Qinghai and Xinjiang in China, and the highlands of Pakistan, Afghanistan, Tajikistan, and Kyrgyzstan (Michaud 2010). Zomia is 'an area marked by a sparse population, historical isolation, political domination by powerful surrounding states, marginality of all kinds, and huge linguistic and religious diversity' (Michaud 2010: 188).

21. Related to this issue, a dramatic event took place in India in August 2012, the exodus of Northeast people (including Nepalis and Tibetans) by train from some South Indian cities after (mostly false) rumours about possible attacks from Muslims on Northeast people in retaliation for the violence in Assam between Bodos and Muslims. The event was not only reminiscent of scenes from the Partition but also revealing about the perceived foreignness of people from Northeast India by other Indians.

22. I thank Hamit Bozarsalan for drawing my attention to this interview.

23. In any case, only two countries that were part of the SEATO were actually Southeast Asian countries: the Philippines and Thailand. The rest included countries like Australia, France, the UK, the US, and so on.

24. And Pakistan can directly interact with Afghanistan.

25. See http://www.saarc-sec.org/SAARC-Charter/5/.

26. According to Pagden (2002: 9), 'a vision of a future in which 'Europe' would acquire some kind of unity'dates back to the days of the Emperor Augustus's new Rome.

27. See also Biancamaria Fontana (2002: 128) who notes that, 'with the settlements of the Congress of Vienna, the modern idea of Europe had reached a point of no return. From now on the European identity would no longer reside in shared traditions, in religious and cultural affinities. It had become a distinctive political reality, the privileged framework within which single nations had to find their place and a mode of coexistence'. 
28. Whether Europeans see the European Union as a political entity is of course another story. See for instance 'L'Europe au tableau noir: comment les instituteurs français enseignent-ils l'Europe aujourd'hui', in which Géraldine Bozec (2010) shows that the school curriculum does not present the EC as a political community but as a collection of countries without a specific meaning; 'Europe between Integration and Globalization', in which Sophie Duchesne et al. (2010) show the indifference of working class people towards European integration in France, Belgium and the UK; 'European Identity and European Citizenship' in which Adrian Favell (2010) shows that a majority of highly mobile Europeans who live and work in another country of the EU remain mainly interested in the politics of their home countries.

29. For a brief but beautifully written summary of these encounters from 750 to 1947, see Manan Ahmad (2013).

30. Bayly (1998: 38) suggests for instance that in order to give legitimacy to his Empire, the Emperor Akbar adopted Indian food and manners.

31. Not only are most marriages arranged but, even on the affectual level, if we are to believe the recently created website, indirom: romance for the South Asian soul (the website has changed its name to Indireads, http://www.indireads.com/), there are commonalities in the way romance is imagined and lived in the Subcontinent. See http://www.bbc.com/news/world-asia-21449819. Bollywood movies have probably played a major role in the process (see below).

32. There are however variations along regions and classes about the parts of the fingers that can be 'dirtied' by the food.

33. Afghanistan shares some historical and cultural commonalities with the Subcontinent, particularly with the border zones of Pakistan, but also with more central parts of the region. See for instance Green (2011) on the intellectual interactions between Afghans and Indian Muslims. However, as compared to the other main countries of the region (with some exceptions, like the Northeast), cultural continuities have been overall limited.

34. See http://old.himalmag.com/component/content/article/794-being-south-southasian.html. 35. I will restrict myself to the two major religions of the Subcontinent although there would certainly be interesting aspects to mention about other religions.

36. While the Tablighi Jama'at has spread worldwide, the Jama'at-i Islami has remained a purely South Asian movement, which has expanded only in the South Asian diasporas.

37. With a difference though between Nepal and Bangladesh in the fluidity of the borders with India: while India and Nepal share an 'open' border as per a bilateral treaty signed in 1950 (Indians and Nepalis can accordingly travel and work across the border), the border between India and Bangladesh has been decreasingly porous with the setting up of a fence that now covers half of the 4,200 kilometre-long border. See the very interesting book edited by Gellner (2013).

38. See in particular Mir (2012) on practices binding communities across religions.

39. See in particular Matringe (1992).

40. See Tiwari (2013).

41. See

https://www.facebook.com/media/set/? set $=a .189113434445210 .38678 .148938045129416 \&$ type $=3$.

42. For instance, a few Nepali, Pakistani and Sri Lankan actors and singers can be seen and heard in Bollywood movies.

43. See movies like Mission Kashmir (Vidhu Vinod Chopra 2000) or Gadar: Ek Prem Katha (Anil Sharma 2001) for instance.

44. The Indian film-maker-cum-journalist, Kabir Khan, excels in that: in Kabul Express (Kabir Khan 2006), there is a scene in which two Indian journalists, a Pakistani driver and a terrorist sing together a Hindi song. Another of his movies, Ek tha Tiger (Kabir Khan 2012), banned in Pakistan, is about the love story between an Indian secret agent (RAW) and a Pakistani secret agent (ISI).

South Asia Multidisciplinary Academic Journal, 10 | 2014 
45. To remain with the example of cinema, some Pakistani movies for instance were able to make their ways into the Indian market, like Khuda ke liye (Shoaib Mansoor 2007) or Bol (Shoaib Mansoor 2011).

46. The issue of cross-border relations, and the subsequent construction of South Asia, is also addressed by art cinema, and in usually less ambivalent ways than Bollywood movies, as illustrates the Pakistani movie Ramchand Pakistani (Mehreen Jabbar 2008), which was granted two awards by the SAARC Film Awards. Starring an Indian actress, Nandita Das, Ramchand Pakistani relates the true story of a little Pakistani Hindu boy, from a Dalit family, who inadvertently crosses the border between India and Pakistan, and the consequences of this action for his family.

47. Before the 26/11 Bombay attacks, India and Pakistan used to play regularly in Test Matches which were organized on the mutual initiative of the cricket Boards of both countries. This explains Mukul Kesavan's statement (2008) that 'every time a Test cricket match between India and Pakistan goes well we're all (temporarily) Southasian.'

48. See the proceedings of the 2008 meeting that took place in Colombo ( http:// www.peoplesaarc.org/index.php/publications).

49. See http://www.peoplesaarc.org/index.php/publications.

50. See also Dixit (2004).

51. As mentioned in the introduction, I use the singular form as I mean here people who endorse the idea that the region forms an entity.

52. Quoted in Khilnani (1997: 198).

53. See Pagden (2002).

54. Patriotism can be translated by wataniyyat.

55. Not as much as in nationalism though, as Romain Gary (1965: 371) puts it: 'le patriotisme, c'est d'abord l'amour des siens, le nationalisme, c'est d'abord la haine des autres' (patriotism is above all the love for one's people, nationalism is above all the hatred of others).

56. See Rimal (2011).

57. For other such ideas, see in particular the August 2008 of Himal Southasian.

58. A plait ornament traditionally worn by South Indian brides.

59. See Mehta (2008).

INDEX

Keywords: South Asia, area studies, Indian Subcontinent, patriotism, region, regionalism, SAARC

\section{AUTHOR}

\section{AMINAH MOHAMMAD-ARIF}

CNRS Research Fellow in anthropology at the Centre for South Asian Studies (CEIAS), EHESS, Paris 